\section{Large-scale chromatin morpho-functional changes during mammalian oocyte growth and differentiation}

\author{
A.M. Luciano, V. Lodde, F. Franciosi, \\ I. Tessaro, D. Corbani, S.C. Modina
}

Reproductive and Developmental Biology Laboratory, Department of Health, Animal Science and Food Safety, University of Milan, Milan, Italy

\section{Abstract}

Mammalian oocyte development is characterized by impressive changes in chromatin structure and function within the germinal vesicle (GV). These changes are crucial to confer the oocyte with meiotic and developmental competencies. In cow, oocytes collected from early and middle antral follicles present four patterns of chromatin configuration, from GV0 to GV3, and its progressive condensation has been related to the achievement of developmental potential. During oogenesis, follicular cells are essential for the acquisition of meiotic and developmental competencies and communicate with the oocyte by paracrine and gap junction mediated mechanisms. We recently analyzed the role of gap junction communications (GJC) on chromatin remodeling process during the specific phase of folliculogenesis that coincides with the transcriptional silencing and sequential acquisition of meiotic and developmental capabilities. Our studies demonstrated that GJC between germinal and somatic compartments plays a fundamental role in the regulation of chromatin remodeling and transcription activities during the final oocyte differentiation, throughout cAMP dependent mechanism(s).

\section{Features and significance of large-scale chromatin configuration changes within the germinal vesicle}

During follicular development, mammalian oocyte acquires a series of competencies that play critical roles at fertilization and subsequent stages of embryonic development. Recent studies indicate that these competencies involve remodeling of chromatin occurring in the germinal vesicle (GV), when gamete and somatic cells communicate throughout junctional and paracrine mediated mechanisms. ${ }^{1}$ Dynamic changes in GV oocyte chromatin structure have been reported in mouse ${ }^{2-4}$ monkey, ${ }^{5}$ pig, ${ }^{6}$ rat, ${ }^{7}$ human, ${ }^{8,9}$ horse,${ }^{10}$ ${ }^{12}$ cattle,,$^{13-16}$ goat, ${ }^{17}$ sheep, ${ }^{18}$ rabbit, ${ }^{19}$ buffalo, ${ }^{20}$ $\operatorname{dog},{ }^{21-23}$ ferret, ${ }^{24}$ and cat..$^{25}$ A direct relationship between oocyte's chromatin configuration and embryonic developmental competence has been proved in mouse $\mathrm{e}^{26,27}$ and cow. ${ }^{13,28}$

In growing mouse oocytes chromatin is initially decondensed in a configuration termed Non-Surrounded Nucleolus (NSN).,4,29 With subsequent growth and differentiation, oocyte nuclear organization undergoes a dramatic change in which chromatin becomes progressively condensed, forming a heterochromatin rim in close apposition with the nucleolus, acquiring a configuration termed Surrounded Nucleolus (SN).,2,29

The morphological differences between these two types of oocytes have a biological relevance as NSN and SN morphologies have been correlated with differences in follicle size, oocyte diameter and the age of the mouse. ${ }^{4,29}$ Several authors indicate that SN oocytes may represent the more advanced stage of preovulatory oocytes. ${ }^{4,26,29}$ In fact, it has been demonstrated that the transition into the SN configuration correlates with the timely progression of meiotic maturation. ${ }^{2-4}$ Furthermore, after in vitro maturation and fertilization, NSN oocytes are incapable of development beyond the two-cell stage, whereas SN oocytes are capable of development to the blastocyst stage ${ }^{26,27}$ Differences in chromatin morphology have also been correlated with changes in transcriptional activity: NSN oocytes remain transcriptionally active and synthesize all classes of RNA, whereas SN oocytes are associated with global repression of transcriptional activity. ${ }^{9,30-33}$

In cow, oocytes collected from early and middle antral follicles present four patterns of chromatin configuration, from GV0 to GV3 (Figure 1) characterized by the progressive increase in condensation ${ }^{13}$ and global DNA methylation. ${ }^{34}$ The GV0 stage shows a diffuse filamentous pattern of chromatin in the whole nuclear area; the GV1 and GV2 configurations represent early and intermediate stages, respectively, of chromatin remodeling, a process starting with the appearance of few foci of condensation in GV1 oocytes and proceeding with the formation of distinct clumps of condensed chromatin in GV2 oocytes; the GV3 is the stage where the highest level of condensation is reached with chromatin organized into a single clump. Importantly, oocytes with a GV0 configuration showed a very limited capacity to resume and complete meiosis I after in vitro maturation, while virtually all the GV1, GV2 and GV3 oocytes were able to reach MII stage, despite their GV configuration. On the contrary, after in vitro fertilization and
Correspondence: Prof. Alberto M. Luciano, Dipartimento di Scienze Veterinarie per la Salute, la Produzione Animale e la Sicurezza Alimentare, Università degli Studi di Milano, via Celoria, 10 - 20133 Milano, Italy.

Tel. +39.02.50317969 - Fax: +39.02 .50317980 .

E-mail: alberto.luciano@unimi.it

Key words: chromatin configuration, developmental competence, gap junctions, oocyte, mammals.

Acknowledgments: this work was supported by Grant n. 26096200 (project "Ex Ovo Omnia") from Regione Sardegna and Lombardia. IT and VL were supported by "Dote ricerca" and "Dote Ricerca Applicata" FSE, Regione Lombardia.

This paper was presented by Prof. Alberto M. Luciano at the XXXIV National Congress of the Italian Society of Histochemistry, San Benedetto del Tronto, Italy, June 7-9, 2011.

Contributions: AML, VL, SM, research theme defining, methods designing, results analysis and interpretation and manuscript writing. VL, IT, FF, DC, laboratory experiments performing. Al authors approved the manuscript final version.

Conflict of interests: the authors declare there is no conflict of interests, personal, financial or otherwise, in relation of this work.

Received for publication: 13 June 2012. Accepted for publication: 2 July 2012.

This work is licensed under a Creative Commons Attribution NonCommercial 3.0 License (CC BYNC 3.0).

(C) Copyright A.M. Luciano et al., 2012

Licensee PAGEPress, Italy

European Journal of Histochemistry 2012; 56:e37 doi:10.4081/ejh.2012.e37

embryo culture, only a limited percentage of GV1 oocytes reached the blastocyst stage, while GV2 and GV3 oocytes showed a higher embryonic developmental potential. ${ }^{13}$

These results further support the general principle that meiotic and developmental competencies are acquired at sequential stages of oogenesis, ${ }^{1}$ alongside with changes in largescale chromatin structure ${ }^{35}$

\section{Oocyte growth, chromatin remodeling and key structural modifications in the nuclear and cytoplasmic compartments}

In the mammalian ovary, oocytes are naturally arrested at prophase I of meiosis and primordial follicle-enclosed oocytes remain in the resting phase until they are stimulated to grow. ${ }^{36}$ 0ocyte growth phase includes a series 
of modifications in the amount, structure and distribution of the organelles as well as a period of oocyte transcription, which are necessary for the oocyte to achieve meiotic and developmental competence. ${ }^{36,37}$ The bovine oocyte and follicle continue to grow in parallel until the follicle reaches a diameter of about $3 \mathrm{~mm}$; thereafter, the oocyte plateaus at about 120 $130 \mu \mathrm{m}$, while the follicle grows up to $15-20$ $\mathrm{mm}$ in diameter before ovulation. ${ }^{36}$ As the oocyte increases in diameter, key structural modifications and redistribution of the cytoplasmic organelles further occur. ${ }^{38}$ Towards the end of the growth phase, the global transcriptional activity decreases and the nucleolus is transformed into an inactive remnant through a mechanism known as nucleolar dismissing. ${ }^{37,39,40}$ In cow, the process of chromatin remodeling is timely related with the morphological changes that occur in both the nuclear and cytoplasmic compartment during oocyte growth and differentiation (Table 1 and Figure 2). ${ }^{13,41}$ Oocytes with a GV0 configuration are the predominant type of oocytes collected from early antral follicles, between 0.5 and $<2 \mathrm{~mm}$ in size, with a mean diameter of $108 \mu \mathrm{m} .{ }^{13}$ These oocytes displayed typical structural features of the growth phase with nuclear characteristics and distribution and structure of the cytoplasmic organelles similar to those previously described in oocyte with a diameter $<110$ $\mu \mathrm{m} .{ }^{38}$ Furthermore, at the nuclear level, GV0 chromatin configuration is always associated with high level of RNA synthesis while the transition to condensed state of the chromatin is associated with global repression of transcriptional activity. ${ }^{28,41}$ With subsequent growth and differentiation, profound changes in chromatin organization occur and the oocytes gradually achieve the full capability for sustaining embryonic development. As a consequence, oocytes collected from mid-antral follicles represent a heterogeneous population of gametes, characterized by different degrees of chromatin condensation and by different embryonic developmental competence. In fact, GV2 and GV3 oocytes exhibited a higher capability to sustain the preimplantation embryonic development when compared to GV1 oocytes. ${ }^{13}$ GV1, GV2 and GV3 stage oocytes, accordingly to their mean diameter (117, 119 and $121 \mu \mathrm{m}$, respective$\mathrm{ly}^{13}$ ) generally showed the morphological appearance that has been previously described in fully grown oocytes. . $^{36-38,42,43}$

Morphological and functional studies in cow described the modifications that typically characterize the bovine oocyte differentiation within the dominant follicle, before the LH surge and during preovulatory development, which is an important step for the attainment of a full developmental competence..$^{37,44}$ These changes are generally referred to as oocyte capacita- $t^{t i o n}{ }^{37}$ and, at the structural level, include, among others, the reduction of the size of Golgi complex and the convolution of the nuclear envelope.

The overall appearance of GV1 oocytes denotes that they have not completed the changes that normally occur in final differentiation. ${ }^{41}$ This could be related with their poor developmental capability. In contrast, both GV2 and GV3 oocytes, accordingly with their higher developmental capability, showed typical signs of pseudo-maturation, ${ }^{44}$ with GV3 oocytes in a more advanced stage of differentiation, as indicated by the global repression of transcriptional activity and the appearance of early cellular degeneration, such as the presence of organelle-free areas, degenerative features of cortical granules ${ }^{41}$ and reduction of the intercellular coupling between the oocyte and cumulus cells. ${ }^{13}$ These observations are in agreement with the hypothesis that GV3 oocytes represent that proportion of gametes which have reached a high developmental capability during follicular growth and that, at the time of collection, are undergoing early events of atresia. ${ }^{13}$ This hypothesis also supports the concept that oocyte developmental competence appears to be improved by low levels of atresia. ${ }^{45-52}$

\section{Oocyte development, chro- matin remodeling and gap junction mediated interplay with cumulus granulosa cells}

Oocyte growth and differentiation depend on the establishment of a patent bidirectional communication mediated by heterologous gap junctions between oocytes and companion granulosa cells during folliculogenesis. ${ }^{53-55}$ In mouse, previous studies indicate that the presence of oocyteassociated granulosa cells are required for the progressive repression of transcriptional activity in fully grown oocytes. ${ }^{32}$ Moreover, the tight association with companion cumulus cells is required to promote the transition from NSN to SN configuration after gonadotropin stimulation. ${ }^{32}$ This hypothesis is supported also by studies where gap junction mediated communications (GJC) between mouse oocyte and cumulus cells were interrupted, due to targeted deletion of the connexin 37 gene (Gja4), and chromatin condensation associated with transcriptional repression failed to occur. ${ }^{56}$

Coupling between oocyte and cumulus cells undergoes dynamic changes during follicle
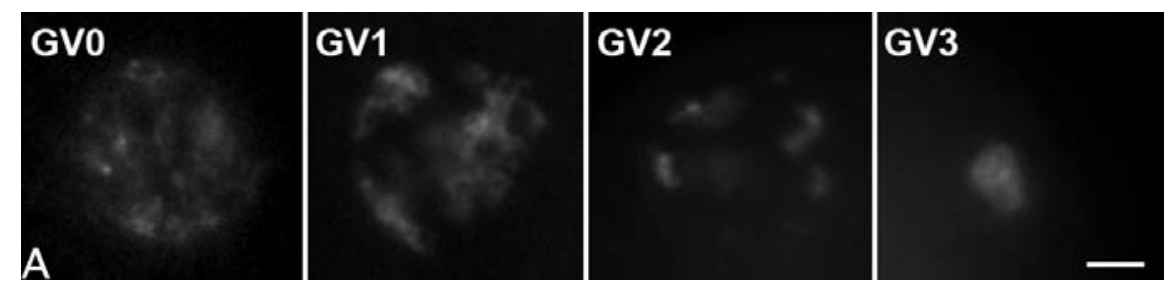

\begin{tabular}{|c|c|c|c|c|c|}
\hline & fyo & & & & \\
\hline & & & & & \\
\hline Diameter & $108.6 \pm 0.7$ & $117.1 \pm 0.8$ & $119.1 \pm 0.7$ & $121.6 \pm 0.6$ & Lodde et al. ${ }^{13}$ \\
\hline $\begin{array}{l}\text { Transcriptional } \\
\text { activity }\end{array}$ & + & \pm & - & - & $\begin{array}{l}\text { Luciano et al., }{ }^{28} \\
\text { Lodde et } a l .^{41}\end{array}$ \\
\hline $\begin{array}{l}\text { Meiotic } \\
\text { competence }\end{array}$ & - & + & + & + & $\begin{array}{l}\text { Lodde et } a l^{13} \\
\text { Luciano et al. }\end{array}$ \\
\hline $\begin{array}{l}\text { Developmental } \\
\text { competence }\end{array}$ & - & \pm & + & + & $\begin{array}{l}\text { Lodde et al., } \\
\text { Luciano et al. }\end{array}$ \\
\hline $\begin{array}{l}\text { DNA global } \\
\text { methylation }\end{array}$ & \pm & ++ & ++ & ++ & Lodde et al. ${ }^{34}$ \\
\hline
\end{tabular}

Figure 1. A) The four patterns of chromatin configuration, from GV0 to GV3 (scale bar: $10 \mu \mathrm{m})$; B) Oocyte size, transcriptional activity, meiotic and developmental competence and DNA global methylation in relation to chromatin configurations. 
development and the patency of GJC between the two compartments decreases in parallel with the meiotic resumption of the oocyte..$^{57-59}$ However, recent studies performed in cow, horse, dog and cat ${ }^{60-63}$ indicated that morphologically healthy oocyte-cumulus cells complexes isolated from antral follicles without evident signs of atresia are a heterogeneous population characterized by different functional degrees of GJC. In cow, in particular, the direct oocyte-granulosa cell communication through gap junction seems a requisite for chromatin remodeling process during the final phase of oocyte growth. ${ }^{13,28}$ This is supported by the evidences that, at the time of collection, the pattern of uncondensed chromatin in GV0 oocytes is associated with fully open GJC. On the contrary, the percentage of oocytes with functionally open communications significantly decreases with the increase of chromatin condensation, from GV1 to GV3 oocytes, ${ }^{13,28}$ indicating that bovine oocytes that reached the highest level of chromatin condensation have a greater probability in loosing their coupling with follicular cells than oocytes with a lower chromatin condensation. ${ }^{13}$ On the other hand, the increase in chromatin condensation may represent a consequence of the premature interruption of communication between oocyte and follicular cells before the final oocyte maturation since the lost of GJC between the germ and somatic compartments has been related with early events of follicular atresia. $^{64}$

The crucial role of GJC in the modulation of chromatin configuration, global transcriptional activity and developmental competence acquisition, has been recently confirmed in bovine oocyte-cumulus cells complexes. The use of culture systems that prolonged GJC, sustained oocyte growth and allowed chromatin to gradually organize from GV0 into the GV1 configuration, thus acquiring the ability to mature and be fertilized in vitro. ${ }^{28}$ When GJ functionality was experimentally interrupted with the uncoupler 1-heptanol, chromatin rapidly condensed and RNA synthesis suddenly ceased. Interestingly, this effect was nullified by the addition to the culture medium of cilostamide, a specific inhibitor of the oocyte-specific PDE3, an enzyme-degrading CAMP ${ }^{65-67}$ indicating that the functional status of GJC may affect both transcriptional activity and remodeling of large-scale chromatin configuration, potentially through cAMP-dependent mechanism(s). ${ }^{28}$ Therefore, besides the well-characterized mechanisms of action by which cAMP is known to regulate meiotic resumption, ${ }^{68,69}$ these results may suggest that cAMP could be also involved in the control of the activity of factors that modulate transcription and large-scale chromatin remodeling during the final phase of oocyte growth and before the resumption of meiosis.

Interestingly, while in mouse the absence of a patent bidirectional communication caused the majority of oocytes to remain transcriptionally active with uncondensed chromatin, ${ }^{32,56}$ in cow GJC disruption by means of 1-heptanol caused premature chromatin condensation and transcriptional interruption. These experimental

models differ substantially in some aspects; thus, it remains to be fully investigated whether this discrepancy might be due to a different physiological status of the animal model or to the growth phase of the follicle from which an oocyte is isolated. Notably, it cannot be excluded

Table 1. Main morphological and structural features of the nuclear and cytoplasmic compartment in bovine oocyte in relation to chromatin configuration (modified from Lodde et al. $\left.{ }^{41}\right)$.

\begin{tabular}{|c|c|c|c|c|}
\hline Nucleus & $\begin{array}{l}\text { GV0 } \\
\text { Eccentric }\end{array}$ & $\begin{array}{l}\text { GV1 } \\
\text { Peripheral }\end{array}$ & $\begin{array}{l}\text { GV2 } \\
\text { Peripheral }\end{array}$ & $\begin{array}{l}\text { GV3 } \\
\text { Peripheral }\end{array}$ \\
\hline $\begin{array}{l}\text { Undulation of the } \\
\text { nuclear envelope }\end{array}$ & Nearly absent & Slight & Profound & Profound \\
\hline Nucleolus & Fibrillo granular & Dense fibrillar & Dense fibrillar & Dense fibrillar \\
\hline $\begin{array}{l}\text { Cytoplasmic } \\
\text { organelles } \\
\text { distribution }\end{array}$ & $\begin{array}{l}\text { Sparse in } \\
\text { the cytosol }\end{array}$ & $\begin{array}{l}\text { Homogeneous in } \\
\text { the oocyte cortex }\end{array}$ & $\begin{array}{l}\text { Homogeneous } \\
\text { in the oocyte } \\
\text { cortex }\end{array}$ & $\begin{array}{l}\text { Clustered in } \\
\text { the oocyte cortex }\end{array}$ \\
\hline Ooplasmic vesicle & Few & Abundant & Abundant & Plentiful \\
\hline Perivitelline space & Absent & Present & Present & Present \\
\hline Microvilli & Erected & Bent & Bent & Bent \\
\hline $\begin{array}{l}\text { Mitochondria } \\
\text { (location) }\end{array}$ & $\begin{array}{l}\text { Round } \\
\text { (small clusters in the } \\
\text { cytoplasm) }\end{array}$ & $\begin{array}{l}\text { Hooded } \\
\text { (deep cortical) }\end{array}$ & $\begin{array}{l}\text { Hooded } \\
\text { (deep cortical) }\end{array}$ & $\begin{array}{l}\text { Hooded } \\
\text { (peripheral) }\end{array}$ \\
\hline Golgi complex & Present & Reduced & Almost absent & Almost absent \\
\hline Cortical granules & $\begin{array}{l}\text { Singular, all over } \\
\text { the cytoplasm }\end{array}$ & $\begin{array}{l}\text { Clustered, deep } \\
\text { cortical }\end{array}$ & $\begin{array}{l}\text { Clustered, } \\
\text { deep cortical }\end{array}$ & $\begin{array}{l}\text { Clustered, } \\
\text { peripheral } \\
\text { (some sign } \\
\text { of degeneration) }\end{array}$ \\
\hline
\end{tabular}

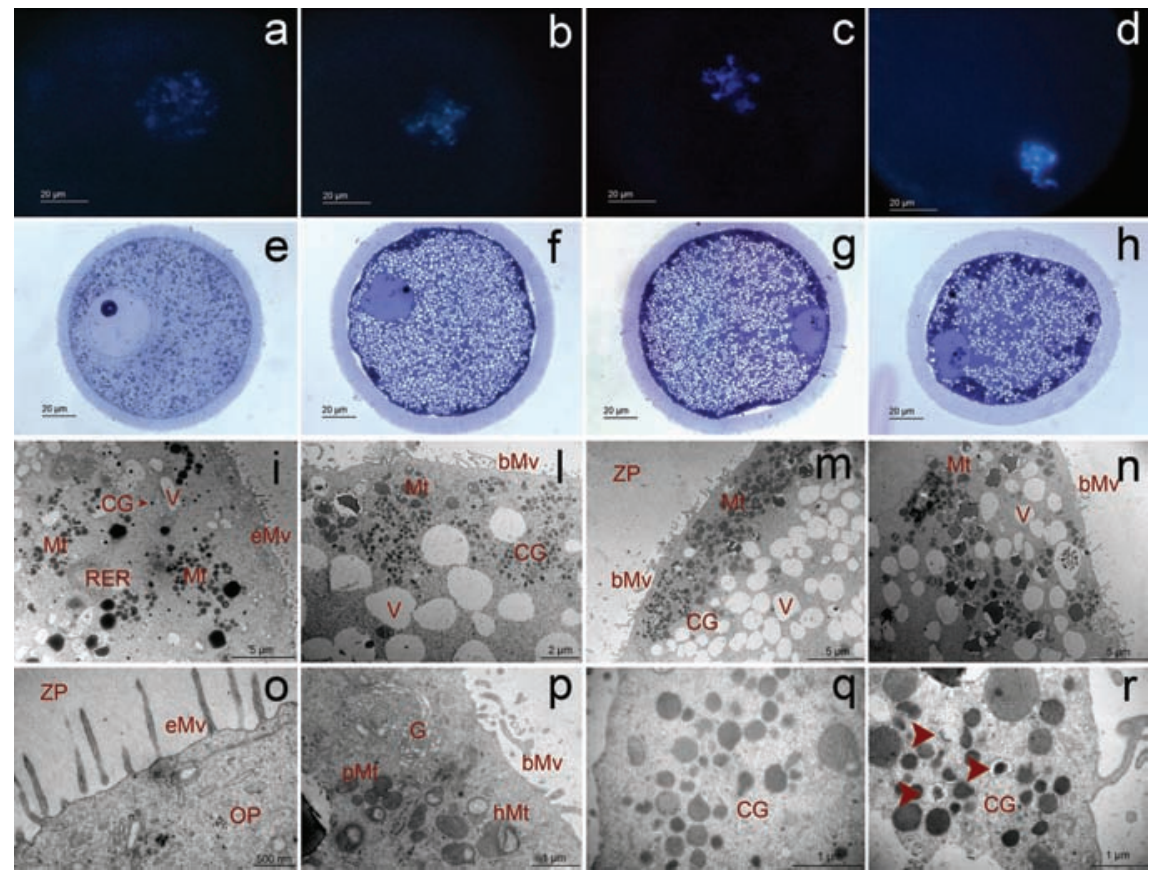

Figure 2. Fluorescence (a, b, c, d), light (e, f, g, h) and transmission (i, l, m, n, o, p, q, r) micrographs representative of GV0 (a, e, i, o), GV1 (b, f, l, p), GV2 (c, g, m, q) and GV3 $(d, h, n, r)$ oocytes. Mt, mitochondria; $V$, vacuoles; $R E R$, rough endoplasmic reticulum; $\mathrm{CG}$, cortical granules; eMV, erected microvilli; bMv, blent microvilli; $\mathrm{ZP}$, zona pellucida; OP, ooplasm; pMt, pleomorphic mitochondria; hMt, hooded mitochondria; G, Golgi complex (from Lodde et al. ${ }^{41}$ ). 
that just the timing when the functional coupling between oocytes and cumulus cells is interrupted could determine the effect on chromatin structural and functional changes. ${ }^{28}$

\section{Conclusions}

The mammalian oocyte nucleus exhibits characteristic chromatin configurations, which are subject to dynamic modifications during oogenesis.

The experimental manipulation of largescale chromatin structure ${ }^{25,28,70}$ can provide a tool to determine the key cellular pathways and factors involved in genome-wide chromatin modifications. Analysis of the functional differentiation of chromatin structure in the oocyte genome in fact have wide-ranging implications for understanding the role of nuclear organization in meiosis, the events of nuclear reprogramming and the spatio-temporal regulation of gene expression during development and differentiation.

Finally, this can provide experimental models to analyze the possible implication of gametes and embryos manipulation in epigenetic disturbances since the process of chromatin remodeling accompanies the epigenetic maturation of the female gamete, which enables an oocyte to develop into a viable embryo after fertilization.

\section{References}

1. Albertini DF, Sanfins A, Combelles CM. Origins and manifestations of oocyte maturation competencies. Reprod Biomed Online 2003;6:410-5.

2. Debey P, Szollosi MS, Szollosi D, Vautier D, Girousse A, Besombes D. Competent mouse oocytes isolated from antral follicles exhibit different chromatin organization and follow different maturation dynamics. Mol Reprod Dev 1993;36:59-74.

3. Wickramasinghe D, Ebert KM, Albertini DF. Meiotic competence acquisition is associated with the appearance of M-phase characteristics in growing mouse oocytes. Dev Biol 1991;143:162-72.

4. Zuccotti M, Piccinelli A, Rossi PG, Garagna S, Redi CA. Chromatin organization during mouse oocyte growth. Mol Reprod Dev 1995;41:479-85.

5. Schramm RD, Tennier MT, Boatman DE, Bavister BD. Chromatin configurations and meiotic competence of oocytes are related to follicular diameter in nonstimulated rhesus monkeys. Biol Reprod. 1993;48:349-56.

6. Bui HT, Van Thuan N, Kishigami S,
Wakayama S, Hikichi T, Ohta $\mathrm{H}$, et al. Regulation of chromatin and chromosome morphology by histone $\mathrm{H} 3$ modifications in pig oocytes. Reproduction 2007;133:371-82.

7. Mandl A. Preovulatory changes in the oocyte of the adult rat. Proc R London (Biol) 1962;41:523-32.

8. Combelles CM, Albertini DF, Racowsky C. Distinct microtubule and chromatin characteristics of human oocytes after failed invivo and in-vitro meiotic maturation. Hum Reprod 2003;18:2124-30.

9. Miyara F, Migne C, Dumont-Hassan M, Le Meur A, Cohen-Bacrie P, Aubriot FX, et al. Chromatin configuration and transcriptional control in human and mouse oocytes. Mol Reprod Dev 2003;64:458-70.

10. Hinrichs K. Cumulus expansion, chromatin configuration and meiotic competence in horse oocytes: a new hypothesis. Equine Vet J Suppl 1997:43-6.

11. Hinrichs K, Schmidt AL. Meiotic competence in horse oocytes: interactions among chromatin configuration, follicle size, cumulus morphology, and season. Biol Reprod 2000;62:1402-8.

12. Franciosi F, Lodde V, Goudet G, Duchamp G, Deleuze $\mathrm{S}$, Douet $\mathrm{C}$, et al. Changes in histone $\mathrm{H} 4$ acetylation during in vivo versus in vitro maturation of equine oocytes. Mol Hum Reprod 2012;18:243-52.

13. Lodde V, Modina S, Galbusera C, Franciosi F, Luciano AM. Large-scale chromatin remodeling in germinal vesicle bovine oocytes: Interplay with gap junction functionality and developmental competence. Mol Reprod Dev 2007;74:740-9.

14. Chohan KR, Hunter AG. Meiotic competence of bovine fetal oocytes following in vitro maturation. Anim Reprod Sci 2003;76:43-51.

15. Fuhrer F, Mayr B, Schellander K, Kalat M, Schleger W. Maturation competence and chromatin behaviour in growing and fully grown cattle oocytes. Zentralbl Veterinarmed A 1989;36285-91.

16. Liu Y, Sui HS, Wang HL, Yuan JH, Luo MJ, Xia P, et al. Germinal vesicle chromatin configurations of bovine oocytes. Microsc Res Tech 2006;69:799-807.

17. Sui HS, Liu Y, Miao DQ, Yuan JH, Qiao TW, Luo MJ, et al. Configurations of germinal vesicle (GV) chromatin in the goat differ from those of other species. Mol Reprod Dev 2005;71:227-36.

18. Russo V, Martelli A, Berardinelli P, Di Giacinto 0, Bernabo N, Fantasia D, et al. Modifications in chromatin morphology and organization during sheep oogenesis. Microsc Res Tech 2007;70:733-44.

19. Wang HL, Sui HS, Liu Y, Miao DQ, Lu JH, Liang $\mathrm{B}$, et al. Dynamic changes of germinal vesicle chromatin configuration and transcriptional activity during maturation of rabbit follicles. Fertil Steril 2009;91:1589-94.

20. Yousaf MR, Chohan KR. Nuclear morphology, diameter and meiotic competence of buffalo oocytes relative to follicle size. Reprod Fertil Dev 2003;15:223-9.

21. Lee HS, Yin XJ, Jin YX, Kim NH, Cho SG, Bae IH, et al. Germinal vesicle chromatin configuration and meiotic competence is related to the oocyte source in canine. Anim Reprod Sci 2008;103:336-47.

22. Jin YX, Lee HS, Yin XJ, Cui XS, Kong IK, Kim $\mathrm{NH}$. Chromatin, microtubule and microfilament configurations in the canine oocyte. Reprod Fertil Dev 2006; 18:849-56.

23. Reynaud K, de Lesegno CV, Chebrout M, Thoumire S, Chastant-Maillard S. Follicle population, cumulus mucification, and oocyte chromatin configuration during the periovulatory period in the female dog. Theriogenology 2009;72:1120-31.

24. Sun X, Li Z, Yi Y, Ding W, Chen J, Engelhardt JF, et al. Chromatin configurations in the ferret germinal vesicle that reflect developmental competence for in vitro maturation. Reprod Domest Anim 2009;44:320-5.

25. Comizzoli P, Pukazhenthi BS, Wildt DE. The competence of germinal vesicle oocytes is unrelated to nuclear chromatin configuration and strictly depends on cytoplasmic quantity and quality in the cat model. Hum Reprod 2011;26:2165-77.

26. Zuccotti M, Rossi PG, Martinez A, Garagna S, Forabosco A, Redi CA. Meiotic and developmental competence of mouse antral oocytes. Biol Reprod 1998;58:700-4.

27. Zuccotti M, Ponce RH, Boiani M, Guizzardi S, Govoni P, Scandroglio R, et al. The analysis of chromatin organisation allows selection of mouse antral oocytes competent for development to blastocyst. Zygote 2002;10: 73-8.

28. Luciano AM, Franciosi F, Modina SC, Lodde V. Gap junction-mediated communications regulate chromatin remodeling during bovine oocyte growth and differentiation through cAMP-Dependent mechanism(s). Biol Reprod 2011;85:1252-9.

29. Mattson BA, Albertini DF. Oogenesis: chromatin and microtubule dynamics during meiotic prophase. Mol Reprod Dev 1990;25:374-83.

30. Bouniol-Baly C, Hamraoui L, Guibert J, Beaujean N, Szollosi MS, Debey P. Differential transcriptional activity associated with chromatin configuration in fully grown mouse germinal vesicle oocytes. Biol Reprod 1999;60:580-7.

31. Christians E, Boiani M, Garagna S, Dessy C, Redi CA, Renard JP, et al. Gene expression and chromatin organization during mouse oocyte growth. Dev Biol. 1999;207:76-85.

32. De La Fuente R, Eppig JJ. Transcriptional activity of the mouse oocyte genome: companion granulosa cells modulate transcrip- 
tion and chromatin remodeling. Dev Biol 2001:229:224-36.

33. Liu H, Aoki F. Transcriptional activity associated with meiotic competence in fully grown mouse GV oocytes. Zygote 2002; 10:327-32.

34. Lodde V, Modina SC, Franciosi F, Zuccari E, Tessaro I, Luciano AM. Localization of DNA methyltransferase-1 during oocyte differentiation, in vitro maturation and early embryonic development in cow. Eur J Histochem 2009;53:199-207.

35. De La Fuente R. Chromatin modifications in the germinal vesicle (GV) of mammalian oocytes. Dev Biol 2006;292:1-12.

36. Fair T. Follicular oocyte growth and acquisition of developmental competence. Anim Reprod Sci 2003;78:203-16.

37. Hyttel P, Fair T, Callesen H, Greve T. Oocyte growth, capacitation and final maturation in cattle. Theriogenology 1997;47:23-32.

38. Fair T, Hulshof SC, Hyttel P, Greve T, Boland M. Oocyte ultrastructure in bovine primordial to early tertiary follicles. Anat Embryol (Berl) 1997;195:327-36.

39. Fair T, Hyttel P, Greve T, Boland M. Nucleus structure and transcriptional activity in relation to oocyte diameter in cattle. Mol Reprod Dev 1996;43:503-12.

40. Maddox-Hyttel P, Bjerregaard B, Laurincik J. Meiosis and embryo technology: renaissance of the nucleolus. Reprod Fertil Dev 2005; 17:3-14.

41. Lodde V, Modina S, Maddox-Hyttel P, Franciosi F, Lauria A, Luciano AM. Oocyte morphology and transcriptional silencing in relation to chromatin remodeling during the final phases of bovine oocyte growth. Mol Reprod Dev 2008;75:915-24.

42. de Loos F, van Vliet C, van Maurik P, Kruip TA. Morphology of immature bovine oocytes. Gamete Res 1989;24:197-204.

43. Fair T, Hulshof SC, Hyttel P, Greve T, Boland M. Nucleus ultrastructure and transcriptional activity of bovine oocytes in preantral and early antral follicles. Mol Reprod Dev 1997;46:208-15.

44. Assey RJ, Hyttel P, Greve T, Purwantara B. Oocyte morphology in dominant and subordinate follicles. Mol Reprod Dev 1994;37: $335-44$.

45. Blondin P, Guilbault LA, Sirard MA. The time interval between FSH-P administration and slaughter can influence the developmental competence of beef heifer oocytes. Theriogenology 1997;48:803-13.

46. Blondin P, Sirard MA. Oocyte and follicular morphology as determining characteristics for developmental competence in bovine oocytes. Mol Reprod Dev 1995;41:54-62.

47. de Loos FA, Bevers MM, Dieleman SJ, Kruip TA. Morphology of preovulatory bovine follicles as related to oocyte maturation.
Theriogenology 1991;35:527-35.

48. Sirard MA, Picard L, Dery M, Coenen K, Blondin P. The time interval between FSH administration and ovarian aspiration influences the development of cattle oocytes. Theriogenology 1999;51:699-708.

49. Wurth YA, Boni R, Hulshof SCJ, Kruip TAM. Bovine embryo production in vitro after selection of the follicles and oocytes. Proceedings of the 12th International Congress on Animal Reproduction, Vol. I, The Hague, The Netherlands, pp. 387-9.

50. Hendriksen PJ, Vos PL, Steenweg WN, Bevers MM, Dieleman SJ. Bovine follicular development and its effect on the in vitro competence of oocytes. Theriogenology 2000;53:11-20.

51. Mermillod P, Oussaid B, Cognie Y. Aspects of follicular and oocyte maturation that affect the developmental potential of embryos. J Reprod Fertil Suppl 1999;54:449-60.

52. Merton JS, de Roos AP, Mullaart E, de Ruigh L, Kaal L, Vos PL, et al. Factors affecting oocyte quality and quantity in commercial application of embryo technologies in the cattle breeding industry. Theriogenology 2003;59:651-74.

53. Eppig JJ. Oocyte control of ovarian follicular development and function in mammals. Reproduction 2001;122:829-38.

54. Matzuk MM, Burns KH, Viveiros MM, Eppig JJ. Intercellular communication in the mammalian ovary: oocytes carry the conversation. Science 2002;296:2178-80.

55. Mehlmann LM, Saeki Y, Tanaka S, Brennan TJ, Evsikov AV, Pendola FL, et al. The Gslinked receptor GPR3 maintains meiotic arrest in mammalian oocytes. Science 2004:306:1947-50.

56. Carabatsos MJ, Sellitto C, Goodenough DA, Albertini DF. Oocyte-granulosa cell heterologous gap junctions are required for the coordination of nuclear and cytoplasmic meiotic competence. Dev Biol 2000;226:167-79.

57. Eppig JJ. The relationship between cumulus cell-oocyte coupling, oocyte meiotic maturation, and cumulus expansion. Dev Biol 1982;89:268-72.

58. Larsen WJ, Wert SE, Brunner GD. A dramatic loss of cumulus cell gap junctions is correlated with germinal vesicle breakdown in rat oocytes. Dev Biol 1986;113:517-21.

59. Larsen WJ, Wert SE, Brunner GD. Differential modulation of rat follicle cell gap junction populations at ovulation. Dev Biol 1987;122:61-71.

60. Colleoni S, Luciano AM, Gandolfi F. Cumulus-oocyte communications in the horse: role of the breeding season and of the maturation medium. Reprod Domest Anim 2004;39:70-5.

61. Luciano AM, Modina S, Vassena R, Milanesi
E, Lauria A, Gandolfi F. Role of intracellular cyclic adenosine 3',5'-monophosphate concentration and oocyte-cumulus cells communications on the acquisition of the developmental competence during in vitro maturation of bovine oocyte. Biol Reprod 2004; 70:465-72.

62. Luvoni GC, Chigioni S, Perego L, Lodde V, Modina S, Luciano AM. Effect of gonadotropins during in vitro maturation of feline oocytes on oocyte-cumulus cells functional coupling and intracellular concentration of glutathione. Anim Reprod Sci 2006; 96:66-78.

63. Luvoni GC, Luciano AM, Modina S, Gandolfi F. Influence of different stages of the oestrous cycle on cumulus-oocyte communications in canine oocytes: effects on the efficiency of in vitro maturation. J Reprod Fertil Suppl 2001;57:141-6.

64. Wiesen JF, Midgley AR, Jr. Changes in expression of connexin 43 gap junction messenger ribonucleic acid and protein during ovarian follicular growth. Endocrinology 1993;133:741-6.

65. Conti M, Andersen CB, Richard F, Mehats C, Chun SY, Horner K, et al. Role of cyclic nucleotide signaling in oocyte maturation. Mol Cell Endocrinol 2002;18:153-9.

66. Sasseville M, Gagnon MC, Guillemette C, Sullivan R, Gilchrist RB, Richard FJ. Regulation of gap junctions in porcine cumulus-oocyte complexes: contributions of granulosa cell contact, gonadotropins, and lipid rafts. Mol Endocrinol 2009;23:700-10.

67. Richard FJ, Tsafriri A, Conti M. Role of phosphodiesterase type $3 \mathrm{~A}$ in rat oocyte maturation. Biol Reprod 2001;65:1444-51.

68. Downs SM. Regulation of the G2/M transition in rodent oocytes. Mol Reprod Dev 2010;77:566-85.

69. Bilodeau-Goeseels S. Cows are not mice: the role of cyclic AMP, phosphodiesterases, and adenosine monophosphate-activated protein kinase in the maintenance of meiotic arrest in bovine oocytes. Mol Reprod Dev 2011;78:734-43.

70. Franciosi F, Perazzoli F, Lodde V, Modina SC, Luciano AM. Developmental competence of gametes reconstructed by germinal vesicle transplantation from fresh and cryopreserved bovine oocytes. Fertil Steril 2010;93: 229-38.

71. Luciano AM, Lodde V, Franciosi F, Tessaro I, Corbani D, Modina S. Gap junction-mediated intercellular coupling controls chromatin remodeling during bovine oocyte growth and differentiation through cAMP-dependent mechanism(s). Proceedings of the 34th National Congress of the Italian Society of Histochemistry, Eur J Histochem 2011;55 (Suppl. 1):5. 